\title{
Experience of Community Leaders in Taking off Pasung (Physical Restraint) for People with Mental Disorders in Southeast Sulawesi
}

\author{
Abdul Patawari ${ }^{*}$, Titin Andri Wihastuti ${ }^{2}$, Nurul Muslihah ${ }^{3}$ \\ ${ }^{1}$ Master of Nursing Study, Program Specialization in Psychology, Faculty of Medicine, \\ Universitas Brawijaya, Indonesia \\ ${ }^{2}$ Department of Public Health Sciences, Faculty of Medicine, Universitas Brawijaya, \\ Indonesia \\ ${ }^{3}$ Department of Nursing, Faculty of Medicine, Universitas Brawijaya, Indonesia \\ Email: abdulpatawaris.kep.ns@gmail.com
}

\begin{abstract}
Mental health problems in Indonesia are still severe, WHO SEARO data for 2017 said that Indonesia is ranked second after India, which is 9. 162. Eight hundred eighty-six patients or around $3.7 \%$ of the population. Mismanagement of health where there are still many people with mental disorders who experience mounting actions that require attention and involvement of all parties, including community leaders. The purpose of writing this research is to explore the experience of community leaders in carrying out pasung (physical restraint) on people with mental disorders in Southeast Sulawesi. The method that researchers use is qualitative research with a phenomenological interpretative. Participants, as many as 7 (seven) people and selected with a purposive sampling approach, were then analyzed using Interpretative Phenomenological Analysis (IPA). The results of the study found three themes, namely community and family stigma against ODGJ (people with a mental disorder), reasons for retention actions and challenges of community leaders in the release of pasung. The conclusion is that the process of releasing pasung cannot be separated from the experience of a figure in the community so that by involving them is expected to eliminate the act of retention in the community.
\end{abstract}

Keywords: Community leaders, Pasung, Experience.

\section{A. INTRODUCTION}

Mental health is a severe problem in the world because the prevalence of the occurrence is still very significant, including in Indonesia. WHO data in the South East Asia Regional Office (WHO SEARO) in 2017, the country of Indonesia ranks second after India, which is 9.162 .886 patients or about $3.7 \%$ of the total population (WHO, 2013).

According to the Basic Health Research (Riskesdas) data of the Republic of Indonesia, the incidence of mental illness increased in 2013 by $1.7 \%$ per mile with an estimated population of 250 million (Statistic, 2017) so that the estimated number of mental disorders is around 425,000 people with a total pasung (physical restraint) of $14.3 \%$ (60,775 inhabitants). Riskesdas (2018) revealed several mental disorders of $1.9 \%$ per mile, with an estimated population of 265 million or around 503,500 people with a 
pasung incidence of $14 \%(70,490$ people). From this figure, the incidence of pasung in the last three months was 31.5\% (22,205 people) (Riskesdas, 2018).

According to data from the Southeast Sulawesi Provincial Health Office (Sultra), the number of mental disorders in 2018 was 1,787 people, and only around 1,147 people $(64.19 \%)$ received health services. From these data, there were still around 152 people with mental disorders living in captivity and in August 2019, the pasung rate had increased to 161 people (Dinkes Sultra, 2019).

Adverse effects of retention in people with mental disorders (ODGJ) are divided into three, namely the physical, psychological and social consequences (Rasmawati, 2018). Adverse physical consequences of injury to the wasting (atrophy) of the muscles (Guan et al., 2015). The psychological consequences of ODGJ can be traumatized, feelings of revenge, especially on families, feeling ostracized, low self-esteem, despair and depression so that the desire to end life appears (Lestari \& Wardhani, 2014). The harmful effect on social life in ODGJ which is put in place, namely the neglect of family and community, arises prejudice and discrimination by the community (Adeosun, Adegbohun, Jeje, \& Adewumi, 2014). While the impact that can be felt by the family is, the family feels pressured both in the community and in the family itself (Chakrabarti, 2016).

Some of the efforts that can be made to reduce containment measures in the community are providing access to mental health services (Suharto, 2014), the success of the Community Mental Health Nursing program (Keliat et al., 2011) and including all essential elements in the community including community leaders (Permenkes RI. No. 54, 2017). The involvement of community leaders in the process of removing pasung is expected to reduce pasung actions. The purpose of writing this research is to explore the experience of community leaders in carrying out pasung on people with mental disorders in Southeast Sulawesi.

\section{B. METHOD}

The research method used in this research was a qualitative method with a phenomenological interpretative that was trying to find meaning by studying more deeply the experiences and challenges faced by community leaders when doing off Pasung. Participants numbered 7 (seven) people and were selected using purposive sampling techniques with:

1. Communityiteria, namely 1) Community leaders

2. Ever in the study site, 2) Ever involved or involved in the

3. Did release pasung, 3) Did not have a $\mathrm{k}$

4. Participantsnts pasung, 4) Participants willing to become a respondent by signing an agreement

5. Willing a participant, 5) Willing to be interviewed and recorded ring the research process. 
Information was collected from participants through in-depth interviews conducted using semi-structured interview guidelines, and all conversations were recorded using a recording device (Handphone). The data analysis process used Interpretative Phenomenological Analysis (IPA). The process began by reading and rereading the verbatim transcript of the interview results, finding keywords, classifying categories, setting themes for each participant, and then combining all themes found in each participant into three (3) themes.

\section{RESULT AND DISCUSSION}

\section{Community and Family Stigma of ODGJ}

Contextually research, the intended stigma is that participants perceive ODGJ based on what is understood so far in the community to give a label or a unique characteristic for people with mental disorders. This theme is composed of several subthemes, which are as follows:

Problems in the family cause mental illness. Three participants said that mental illness was caused by problems in family life either because of living / being separated from a partner, living by a loved one, or because of psychological pressure in the family itself. The following quote from the participant:

"LB divorced with his wife" (R3)

"while WI was left by her husband"(R1)

She started to get ill when he lost his father (R2)

Maybe it happened because the pressure from her family that made her depressed (R5)

Believe that mystical things cause mental illness. Four participants believe that a person can suffer from mental disorders because there is influence from mystical events. Participants believe that ODGJ is sick because of being possessed by spirits, being disturbed by forest watchmen or being exposed to witchcraft. Also, one participant revealed the reason the family refused medical treatment because according to residents' belief, the disease was caused by a supernatural thing that had to be treated by smart people. Participants also expressed their fear of approaching ODGJ due to this belief. The following quote from the participant:

We believe that the only way to cure people with mental illness is by treatment from paranormal (R2)

We believe that there is a spirit at the forest at the back of his house, it is a sago forest, then when she came back, she can't speak, eat and starring at something unknown (R3

Her father said that she got lousy magic from a man who used to be her boyfriend (R5)

People at this village still believe a supernatural thing, that's why we brought her to be paranormal (R7)

Feeling doubt about medical treatment. Two participants expressed doubts about the medical treatment to be given to people with mental disorders. Participants also conveyed an understanding of the community who doubted by medical treatment, 
arguing that mental illness has never healed despite medical treatment everywhere. The following quote from the participant:

We doubt whether people can be cured at the hospital (R2)

People at the village was also doubted about the treatment at a hospital (R4)

We think that she will never be cured totally because it happed a long time ago, it is part of her life (R4).

Every individual has unique characteristics that are inherent in him. These characteristics are considered as something that can distinguish them from others. Characteristics are given through the sensing process so that they can be seen, heard, felt and so on. People with mental disorders also have characteristics or signs that are attached to him, but these characteristics are sometimes negative meaning that is often referred to as stigma.

Stigma or negative characteristics are given to ODGJ based on what is seen, observed, known and understood by the participants. According to Shrivastava, Johnston, \& Bureau (2012), the stigma will harm the quality of health services. Besides, stigma is also responsible for the client's delay in seeking treatment for patients and can influence the therapy that has been given. Stigma is caused by the lack of knowledge, nature of the disease, and the behaviour displayed by people with mental disorders that have an impact on self-esteem and acts of discrimination (Shrivastava et al., 2011).

Participants assume that mental illness is related to problems in the family and mystical matters. Problems in the family are described as divorce or because of the death of a close person so that it becomes a source of stressors for people with mental disorders. For the people of Southeast Sulawesi (Sultra) divorce in the family and the death of the closest person at a young age is a failure so that it can become a stigma (discussion material) for the surrounding community.

According to The Holmes \& Rahe Life Stress Inventory in Wuryaninggsih et al., 2018) divorce and death of close family including 43 life events that are considered to be a source of a stressor or life pressure so that someone who experiences it tends to have a vulnerability to stress. Stuart (2013) said that when someone faces a stressor, he will tend to use coping mechanisms that are owned to overcome these problems. Inability to overcome problems positively (constructively) will cause sufferers to experience mental health problems. Aini (2013) in (Rasmawati, 2018) said that from the survey results one of the causes of mental disorders is problems in marriage (divorce) and also the death of a loved one.

Mental disorders for Southeast Sulawesi people are often associated with mystical things like magic and plagues due to breaking a taboo. Participants said that one of the ODGJ was exposed to magic or compassion, which in Southeast Sulawesi is often called Pole More. Pole more is done by men who feel hurt due to rejection and humiliation from the woman he likes. Another mystical thing that was described by the participants was the plague that struck ODGJ as a result of entering the sago forest 
without permission. For the Southeast Sulawesi community, sago trees are considered sacred because a tree can provide food (sago = traditional food) so to enter or harvest must go through several conditions such as giving offerings and so on.

A similar view develops in foreign countries as expressed by Abera, Robbins, \& Tesfaye, (2015) who researched in Southwestern Ethiopia, stating that out of 532 participants there were about $93,2 \%$ of mental disorders caused by magic power, 81 . Curses cause $8 \%$, and $73.9 \%$ is due to the sin committed by the patient. Laird, Curtis expressed the same thing, \& Morgan (2017) in America who stated that mental health problems were firmly related to spiritual and religious life and culture where they believed that the process of illness and healing could not be separated from the influence of ghosts, spirits, magic and relationships with people who have died.

Suhaimi (2015) said that supernatural power and supernatural powers only become external factors that influence the state of the soul. Still, if the individual is psychologically and spiritually healthy, it can be ascertained that he will avoid the disease. The conclusion of his research is the same as medical science (health) which states that supernatural powers and occult things are not the primary factors causing mental disorders.

Participants also had doubts about medical treatment. Doubt according to KBBI (2016) is feeling hesitant to make choices while according to research doubt what is meant is that participants feel distrustful of medical treatment because many ODGJ patients until death do not show an increasingly better condition even during periods of illness often recurrence. The development of stigma at the research site caused mental disorders sufferers not to get proper treatment; this happened because they did not know how to care and how to get services. As a result of this stigma, alternative medicine is an option because there are various opinions about mental illness, which, of course, hurts ODGJ. According to Henderson, Evans-Lacko, \& Thornicroft (2013) globally, more than $70 \%$ of people with mental disorders did not receive health / medical services due to lack of knowledge to recognize and identify the causes of mental illness which then affected delays and efforts to avoid treatment medical. He further said that the limitations of this information could also cause prejudice to the acts of discrimination of people with mental disorders.

An understanding of mental disorders determines the type of treatment that will be chosen if the family is more likely to stigmatize mental illness caused by mystical matters eating treatment will be more to alternative ways. According to Wardani et al., (2012) family and community misunderstanding related to mental disorders both early symptoms, disease processes and treatment options will cause patients not to get excellent service, avoid treatment, take action pasung, and the emergence of different perspectives in dealing with patients mental disorders. 


\section{Reasons for the Containment Action}

Contextually research, the reason being intended is the things that underlie the participant justify and participate in the act of retention in people with mental disorders. This theme is composed of several sub-themes, which are as follows:

ODGJ has deviant behaviour. Seven participants expressed behaviour that is often shown by people with mental disorders who are considered as something wrong/deviate from the rules-the rules of behaviour should be. The behaviour of people with mental disorders that often arises is raging, angry, angry, like to be alone, wandering, beating other people, insomnia, disturbing others, talkative and efficiently offended. Participants also said that people with a mental health condition are insane people because of their mental disorders. The following quote from the participant:

But she prefers staying in her room and not going out (R1)

I think people who annoy people around the village could be categorized as people with mental illness (R2)

She started to angry and chasing kids (R3)

At first, she started to get angry quickly, and she got less sleep (R4)

Yes, she spoke nonsense (R4)

Suddenly, she got crazy by pulling off her hair, her vital organ, yelling, getting naked, talking nonsense, and act like a crazy person, it happened for a long time, maybe one month (R5)

At first, she looks like a dummy (R6)

People like her are easy to get mad (R7)

Feel the treatment that has been done does not cure ODGJ. Participants said that people with mental disorders so far, only use the media of shamans or smart people and avoid medical treatment, but the condition is getting worse so that ODGJ lives locked up. The following quote from the participant:

We never tried treatment at the hospital, we just tried treatment at paranormal (R1)

Aaaa, we brought her to be paranormal, and there's no change (R2)

I don't know, people said that the treatment would affect well to her in one or two days, but her case was different, she keeps yelling and angry (R4)

We think it will get worse if we do nothing, so sometimes we brought her into Kyai (leader of a particular religion in an area) (R5)

The reason, according to this research, is that everything that is the basis for participants, families, and communities justifies and takes part in carrying out acts of retention. Participants assume that ODGJ has a behaviour that is not fair, dangerous and not accepted because it is contrary to the rules/norms in society. Norms are a set of manners or rules that are not written and are used to regulate social life. Some ODGJ behaviours such as tantrums, anger without cause, hitting, talkative, annoying and easily offended are considered deviant behaviour. Notwithstanding what is referred to 
in this research is the behaviour of ODGJ that violates the habits or norms that can be accepted by the community so that it is considered insane or crazy.

Nasir, A., \& Muhith (2011) describe mental disorders as a form of deviation in behaviour that occurs due to emotional distortion that manifests in a variety of unusual behaviour. According to Wuryaninggsih et al., (2018) behavioural deviations in people with mental disorders, one of which is marked by the belief ODGJ towards something unacceptable because it is contrary to the values of cultural norms that exist in society such as behaving strangely, the road without purpose and performing violent behaviour without an apparent reason. Boyd (2012) also stated a similar thing, namely a mental disorder characterized by behaviour deviations that occur as a result of damage to the mind, mood and behaviour.

The views of community leaders in Southeast Sulawesi regarding deviant behaviour displayed by people with mental disorders are illustrated through dangerous behaviours such as tantrums, anger, often annoying and easily offended. This opinion was not only valid in the research area, but further in a study conducted by Zhang et al., (2020) in six Asian countries namely China, Hong Kong, Japan, Singapore, Korea and Thailand also had a perception that the same is the belief that people with mental disorders, especially schizophrenia and bipolar disorder have dangerous and aggressive behaviour.

Public figures differ in their views on how to deal with mental disorders. This view arises because of the limited information about mental illness that affects the knowledge of participants. Participants considered that alternative therapies such as traditional healers and smart people as well as pasung actions were the solution to overcome the ODGJ problem. Yancen (2015) in Hasanah (2019) said that the lack of knowledge would affect the quality of decision making, which is most detrimental to people with mental disorders. This statement was reinforced by Lestari \& Wardhani (2014), who concluded that the lack of knowledge would have an impact on delays and errors in the delivery of therapy. Abera et al., (2015), in their research, said that around $92.7 \%$ of families sought medical help from spiritual experts or religious leaders because of their understanding.

\section{Challenge Community Leaders in the Release of Pasung}

Contextually research, the intended challenge is the problems experienced by ODGJ which are installed so that it becomes a motivation for community leaders in overcoming these problems. This theme is composed of several sub-themes, which are as follows:

Recognizing the lack of personal hygiene of patients pasung. Four participants said that the condition of people with a mental health condition was filthy, smelly, and clogged because, during their stay at ODGJ, they had never taken a bath and were not taken care of. Furthermore, participants revealed that he was unable to smell the scent 
of the patient's body because the patient was mixed with his faeces. The following quote from the participant:

She looks so dirty because she eats and defecates there, never taking a shower and etcetera (R1)

The smell is so bad; the poops are everywhere, no one wants to clean those, so we left that (R7)

That place is full of moss because no one has ever taken care of her (R4)

Her parents just leave her like that, her skin becomes dark like soil (R6)

Feel pasung inhumane actions. Five participants said that pasung action is inhumane because it treats humans like animals. One participant said that the pasung is worse than an animal cage because the patient has to mix with his faeces and also pet faeces. Furthermore, participants felt sorry because at the patient's confinement site could not move, and humans should be treated as humans, not animals that must be bound. The following quote from the participant:

We feel sorry to look her tied like an animal; I feel that because I know that she is human like us (R1)

We did pasung to her by using long wood which has tho holes for her feet. People tight the wood using screws. It makes her difficult to move, and she just sits there the whole day (R2)

We feel sorry to did that to her, she is a human not animal, If a newcomer come and see that, they feel pity to her because the place is so dirty (R4)

This is not human; we treat her like an animal (R6)

Sometimes we feel sorry to see our goats get rain, but we feel deeper sorry to see those patients (R7)

Be aware that a long pasung can cause disability. Three participants felt sorry because of the condition of the people living with a mental disorder who had been shrunk so that it was difficult to walk. Participants also realized that the problem arises due to the tremendous pasung action that resulted in people with mental disorders such as people who are paralyzed. The following quote from the participant:

We confused to let her free or not; we saw that her legs became small because pasung for a long time, we think to let her free lately (R2)

LA's feet were chained for a long time ago, that's why her legs became small or may be paralyzed. Back in the past, she did not look like that (R4)

I think most of the patients like her were having paralyzed on their feet ( $R 7$ )

The act of retention that occurs in ODGJ becomes a challenge for the participants. The challenge referred to in this study is the desire of participants to overcome all obstacles that occur people with mental disorders, families and communities in the release of pasung. This challenge involves participants' feelings and emotions where according to KBBI (2016) the word feeling has meaning, that is an opinion on something that involves mental (heart) considerations using the senses while emotion means an 
overflow of feelings that develop in a person but recedes in a short time. These feelings and emotions arise because the participants are concerned about the problems faced by the group they lead.

Participants are also aware and believe that pasung on ODGJ can cause poor personal hygiene because patients are not taken care of, disabilities and sufferers must be willing to live apart from family. Participants understand that pasung is not the correct health solution, but regular treatment at the hospital is what they should do. According to research conducted by Zhang et al., (2018) in Hebei Province (China) stated that in 2012 there were around 36 patients (33.6\%) and an increase in 2016 was around 53 patients $(49.5 \%)$ who experience worse health conditions after being locked up (detained at home). The reason is that it was locked up again; there was no follow up treatment until the patient died and the lack of family support.

The need for self-care, including basic needs that must be met by humans because one of the characteristics of a healthy soul is the ability of individuals to care for themselves. People with mental disorders are not able to meet their hygiene needs, this is due to disturbance of thought processes and decreased ability to care for themselves so that they need others including nurses and family (Wuryaninggsih et al., 2018).

Herdman \& Kamitsuru (2014) in NANDA (North American Nursing Diagnosis Association) divides lack of self-care into four, namely lack self-care bathing, dressing/dressing, eating and toileting. The four problems of lack of self-care are experienced by people with psychiatric disorders who are incarcerated. According to research by Halida, Dewi, \& Rasni, (2016), the fulfilment of the need for self-care in people with mental disorders cannot be done independently because of lack of interest and motivation to conduct self-care. The need for self-care requires an active role from others, especially families as caregivers.

In addition to a lack of personal hygiene, long fitting action can also cause smaller legs. This condition is described by participants as a disability in the legs and is considered paralyzed because they are unable to walk normally. A study on the impact of pasung conducted by the Community Psychiatry Division of the Faculty of Medicine, the University of Indonesia in 2006-2007 on 15 people with schizophrenia in Samosir, North Sumatra, and Bireuen, Aceh, found that ODGJ members had shrunk due to long periods of pasung (10 years) (10 years) (Lestari, et al., 2014). Old Pasung can cause disability, so that daily meeting need requires help and support from the family (Yusuf, et al., 2017). The country of Indonesia is one of the countries with the highest mortality and disability due to schizophrenia compared to other countries in the world (Brooks et al., 2018).

Pasung is an inhumane act so that it becomes a problem that must be addressed immediately. Astuti (2017) states that the condition of psychiatric sufferers in pasung very concerns, especially in the fulfilment of their rights as human beings. The cause is estimated because the family does not know about mental illness, what their rights are 
and what efforts should be made. Permenkes RI No. 54, (2017), firmly says that pasung actions are behaviours that violate human rights. Any individual who intentionally acts violently neglects commits violence or provides advice to carry out such acts that violate the rights of patients as humans will be convicted by statutory provisions (UU RI No. 18, 2014).

\section{CONCLUSION}

The experience of community leaders in taking off pasung does not escape the influence of negative stigma that develops in the community. Also, the deviant behaviour of patients and treatment efforts that are considered not to provide maximum results are the reasons that justify them taking action pasung. Awareness of community leaders about the pasung impact that can cause disability, lack of personal hygiene of the patient and is an inhumane action becomes a challenge that must be resolved.

\section{REFERENCES}

1. Abera, M., Robbins, J. M., \& Tesfaye, M. (2015). Parents' perception of the child and adolescent mental health problems and their choice of treatment option in southwest Ethiopia. Child and Adolescent Psychiatry and Mental Health, 9(1), 1-11.

2. Adeosun, I. I., Adegbohun, A. A., Jeje, O. O., \& Adewumi, T. A. (2014). Experiences of discrimination by people with schizophrenia in Lagos, Nigeria. Journal of Public Mental Health, 13(4), 189-196. https://doi.org/10.1108/JPMH-06-2013-0038

3. Astuti, M. (2017). Condition Of Persons With Mental Disorders Who Are Stocks Of Feet Ooden Holes ( ODGJ Pasung), Their Families And Communities In Kabupaten 50 Kota. Sosio Konsepsia, 6(3), 256-268.

4. Boyd, M. A. (2012). Psychiatric Nursing Contemporary Practice. Philadelphia Lippincott.

5. Brooks, H., James, K., Irmansyah, I., Keliat, B. A., Utomo, B., Rose, D., ... Lovell, K. (2018). Exploring the potential of civic engagement to strengthen mental health systems in Indonesia (IGNITE): A study protocol. International Journal of Mental Health Systems, 12(1), 1-10.

6. Chakrabarti, S. (2016). Research on family caregiving for mental illness in India and its impact on clinical practice: Are we doing enough to help families? Indian Journal of Social Psychiatry, 32(1), 19-25

7. Dinkes. (2019). Dinas Kesehatan Provinsi Sulawesi Tenggara. Kendari.

8. Guan, L., Liu, J., Wu, X. M., Chen, D., Wang, X., Ma, N., \& Wang, Y. (2015). Unlocking Patients with Mental Disorders Who Were in Restraints at Home: A National Follow-Up Study of China's New Public Mental Health Initiatives. PLoS ONE, 1, 1-15. 
9. Halida, N., Dewi, E. I., \& Rasni, H. (2016). The Family Experience in Fulfilling the Needs of the Self-care of people with Chronic Mental Health Illness (ODGJ) with Seclusionin Ambulu Sub-District Jember Regency. E-Jurnal Pustaka Kesehatan, 4(1), 78-85. Retrieved from http://dspace.unej.ac.id/handle/123456789/65879?show=full

10. Hasanah, U. (2019). The effect of health education on knowledge and attitudes about cesarean in Tehrani women. Jurnal Keperawatan Jiwa, 7(1), 87-94. Retrieved from e-ISSN 2655-8106 p-ISSN2338-2090

11. Henderson, C., Evans-Lacko, S., \& Thornicroft, G. (2013). Mental illness stigma, help-seeking, and public health programs. American Journal of Public Health, 103(5), 777-780.

12. Herdman, T., H., \& Kamitsuru. (2014). NANDA International Nursing Diagnoses: Definitions $\mathcal{E}$ Classification, 2015 - 2017. Oxford: Wiley Blackwell.

13. KBBI. (2016). Retrieved from https://kbbi.web.id.

14. Keliat, B.A, Akemat, Helena Novy, dan N. H. (2011). Keperawatan Kesehatan Jiwa Komunitas CMHN (Basic Course). Jakarta: EGC.

15. Laird, L. D., Curtis, C. E., \& Morgan, J. R. (2017). Finding Spirits in Spirituality: What do We measure in Spirituality and Health Research? Journal of Religion and Health, 56(1). https://doi.org/10.1007/s10943-016-0316-6

16. Lestari, P., Choiriyyah, Z., \& Mathafi. (2014). Kecenderungan Atau Sikap Keluarga Gangguan Jiwa Terhadap Tindakan Pasung ( Studi Kasus Di RSJ Amino Gondho Hutomo Semarang. Keperawatan Jiwa, 2(1), 14-23. Retrieved from https://jurnal.unimus.ac.id/index.php/JKJ/article/view/3917/3649

17. Lestari, W., \& Wardhani, Y. (2014). Stigma and Management on People with Severe Mental Disorders with "Pasung" (Physical restraint). Buletin Penelitian Sistem Kesehatan, 17(2 Apr), 157-166. https://doi.org/10.22435/bpsk.v17i2

18. Nasir, A., \& Muhith, A. (2011). Dasar-Dasar Keperawatan Jiwa. Pengantar dan Teori. Jakarta: Salemba Medika.

19. Permenkes. (2017). Peraturan Menteri Kesehatan Republik Indonesia Nomor 54 Tahun 2017 Tentang Penanggulangan Pemasungan Pada Orang Dengan Gangguan Jiwa.

20. Rasmawati. (2018). Studi Fenomenologi Pengalaman Hidup Orang Dengan Gangguan Jiwa Pasca Pasung Yang Mengalami Perceraian. Islamic Nursing, 3(1), 100-105.

21. RI, D. (2014). Undang-Undang Nomor 18 Tahun 2014 tentang Kesehatan Jiwa. Undang-Undang Nomor 18 Tahun 2014 Tentang Kesehatan Jiwa, (185). Retrieved from http://ditjenpp.kemenkumham.go.id/arsip/ln/2014/uu18-2014bt.pdf

22. Riskesdas. (2018). Riset Kesehatan Dasar Republik Indonesia. Jakarta.

23. Shrivastava, A., Johnston, M., \& Bureau, Y. (2012). The stigma of Mental Illness-1: Clinical reflections. Men's Sana Monographs, 10(1), 70-84. https://doi.org/10.4103/0973-1229.90181 
24. Shrivastava, A., Johnston, M. E., Thakar, M., Shrivastava, S., Sarkhel, G., Sunita, I., \& Parkar, S. (2011). Impact and Origin of Stigma and Discrimination in Schizophrenia: Patient Perceptions. Stigma Research and Action, 1(1), 67-72. https://doi.org/10.5463/sra.v1i1.5

25. Statistik, B. P. (2017). Data Kependudukan Indonesia. Jakarta.

26. Stuart, G. (2013). Psychiatric Nursing (10th ed.). Jakarta: EGC.

27. Suhaimi. (2015). Gangguan Jiwa Dalam Perspektif Kesehatan Mental Islam. Jurnal RISALAH, 26(4), 197-205.

28. Suharto, B. (2014). Budaya Pasung dan Dampak Yuridis Sosiologis (Studi Tentang Upaya Pelepasan Pasung dan Pencegahan Tindakan Pemasungan di Kabupaten Wonogiri). Indonesian Journal on Medical Science, 1(2). https://doi.org/Poltekkes Bhakti Mulia Sukoharjo.ijmsbm.org

29. Wardani, I. Y., Hamid, A. Y. S., Wiarsih, W., \& Susanti, H. (2012). Dukungan Keluarga: Faktor Penyebab Ketidakpatuhan Klien Skizofrenia Menjalani Pengobatan. Jurnal Keperawatan Indonesia, 15(1), 1-6.

30. WHO. (2013). Mental Health Action Plan, 2013 -2020. Geneva: World Health Organization.

31. Wuryaninggsih, E. W., Windarwati, H. D., Dewi, E. I., Deviantony, F., \& Hadi, E. (2018). Buku Ajar. Keperawatan Kesehatan Jiwa 1. Jember: UPT Percetakan \& Penerbitan Universitas Jember.

32. Yusuf, A., Tristiana, R. D., \& Ms I. P. (2017). Grasped Phenomena and Family Support on Post Grasped Psychiatric Patients. Keperawatan, 5(3), 302-314. Retrieved from http://jkp.fkep.unpad.ac.id/index.php/jkp/article/view/653

33. Zhang, Y. S., Li, K. Q., Sun, J. H., Li, W., Tong, Z. H., Yan, B. P., ... Xiang, Y. T. (2018). Long-Term Outcomes of Unlocking Chinese Patients with Severe Mental Illness. Psychiatric Quarterly, 89(3), 757-763. https://doi.org/10.1007/s11126-018-95756

34. Zhang, Z., Sun, K., Jatchavala, C., Koh, J., Chia, Y., Bose, J., ... Ho, R. (2020). Overview of stigma against psychiatric illnesses and advancements of anti-stigma activities in six Asian societies. International Journal of Environmental Research and Public Health, 17(1). https://doi.org/10.3390/ijerph17010280 